\title{
Teaching Health Care Ethics IN PHYSIOTHERAPY EDUCATION: PROPOSAL FOR SOUTH AFRICA
}

\begin{abstract}
This paper presents views of the role of the physiotherapy profession during the Apartheid era in South Africa. It analyses aspects of the Truth and Reconciliation Commission document and finally suggestions are made to prevent similar situations from developing ever again.
\end{abstract}

MOLATOLI HM ( NEÉ LEBELOANE) BSC (MEDUNSA), Dip.tert. Ed (UP)

\section{KEYWORDS: ETHICS, TEACHING, EDUCATION}

\section{INTRODUCTION}

Throughout history, groups of health care professionals, including physiotherapists formulated ethical policies and declarations called The Code of Ethics. The Code of Ethics are self regulatory laws to guide practices and behaviours of professional members (Purtillo 1983; Engelhardt, 1996; Loewy, 1996). The Code of Ethics has been influenced by many issues such as religion, science and law. These have made it difficult to guarantee the interpretation and implementation of The Code of Ethics in clinical practice. This is due to the fact that health professionals are often reactive rather than pro-active in anticipating ethical issues.

\section{HISTORICAL BACKGROUND}

Since medieval times, religion has contributed greatly to health care on issues such as charity, virtue and holistic healing. Religion, on the other hand, has also had a direct or indirect contribution to some of the most immoral systems experienced in modern times. Examples of these are the contribution of the Dutch Reformed Church to Apartheid in South Africa and the possible role of the Catholic Church during the Nazi era. In modern times, religion is still regarded as an important determinant of ethical behaviour and there is failure to recognise that many influences, inspirations and beliefs have also guided good deeds in health care ( Loewy, 1996).

As medicine became more scientific, health care progressively became domi- nated by value free, objective and quantitative science. Moral beliefs had limited roles in shaping the future of health care practice. Emphasis was given to the application of scientific principles to cure disease and this led to the neglect of the social context in which diseases take place. Other role players became interested in health care and their interest was not only health but profits and political benefit, and they were willing to achieve their aims at all costs (Callaghan and Bok, 1980; Engelhardt, 1996; Loewy, 1996 ).

As health care professionals disengaged themselves from social actions and health care delivery, politicians filled their places. Health care suffered from moral neglect and this led to the exploitation of health by political and legal disciplines to their own advantage. Ethics was reduced to law. The health profession failed to recognise that what is legal is not necessarily ethical but that ethics is the basis of the law (Callaghan and Bok, 1980; Engelhardt, 1996; Loewy, 1996).

\section{THE SOUTH AFRICAN CONTEXT}

Apartheid was a socio- political and constitutional system based on deep racism that deprived black people of respect and dignity of person. It was systemic and institutionalised in all areas of civic life and manifested in health care as:

- rigid segregation of health care facilities

- disproportionate allocation of physical and financial resources
In addition to the above, black patients were treated in overcrowded and dirty facilities, resulting in a lack of privacy and confidentiality. Professionals and personnel at health care institutions were expected to put the law and security of the state ahead of their ethical commitment to a patient's well being.

The Truth and Reconciliation Commission (TRC) was set up by the democratic South African government in 1995, with a mandate to examine "as complete a picture as possible of the causes, nature and extent of the gross violations of human rights". The role played by health professionals in the creation and maintenance of an environment in which human rights had been violated was also to be examined (Promotion of National Unity and Reconciliation Act 1995 3(1) (d)). The physiotherapy profession had an opportunity to make submissions to the TRC, acknowledging how they contributed to the creation and maintenance of Apartheid. The physiotherapy profession identified the need to improve the teaching of health care ethics and educate physiotherapists on

CORRESPONDENCE:

HM Molatoli (neé Lebeloane)

Faculty of Medicine

Department of Physiotherapy

University of Pretoria

P.O. Box 667 Pretoria 0001

South Africa

Tel: (012) 463-6734

E-mail: (012) linky@mweb.co.za 
aspects of human rights as one of the most important issues to prevent future violations of human rights in health care (Physiotherapy TRC submission document 1998).

\section{THE TEACHING OF HEALTH CARE ETHICS}

The subject of health care ethics does not enjoy the same attention and status as other scientific subjects within the health professional's education. The teaching of health care ethics has always been eclectic, scarce and frequently placed at the periphery of the medical curriculum ( Pond's Report, 1987; Burling et al, 1990; Ashcroft et al, 1998). In 1996 Lebeloane conducted a study on the status of health care ethics at South African universities, the results showing that it is still in its infancy and taught at a very superficial level.

There is a growing acknowledgement that health care ethics has an important place within the education of health care professionals. There is also a concerted effort by medical training institutions to formalise the teaching of this subject. In Britain, the General Medical Council set up a commission in 1987 that produced the Pond Report. In 1998 another commission made recommendations on the content and the implementation of health care ethics in medical training in the UK (Ashcroft et al, 1998; Pond Report, 1987). In America, The Hasting Centre, an Institute of Society, Ethics and Life Science embarked on a most extensive research project between 1977 and 1979. The aim of this project was to assess the status, problems and possibilities associated with the teaching of ethics in Higher Education. The report recommended that if any course of ethics is to be held in high esteem, it should at least attend to five general educational goals (Callaghan and Bok, 1980). These are to:

1. stimulate moral imagination

2. raise awareness of ethical issues,

3. develop analytical and communication skills,

4. improve tolerance of ambiguity and diversity

5. elicit a sense of moral obligation to social responsibility.

Since the mid 1970's health care ethics has been gaining a high profile and becoming more prominent within the literature of the nursing and medical professions. However, despite the constant and ever growing attention given to this component in clinical practice by other health care professionals, physiotherapy continues to neglect to address the issue (Guccionne 1980; Barnit 1993; Clawson 1994; Triesenberg 1996). The objective of this review was to discuss the five general educational goals of health care ethics in relation to South Africa, with the hope that it will facilitate the discussions on education in South Africa and internationally.

\section{EDUCATIONAL GOALS OF HEALTH CARE ETHICS}

To meet the demand of society the goals of teaching health care ethics have to meet the immediate and future needs of the profession. They should be broad to include cognitive knowledge of health care ethics, affective and directive skills. The five general education goals are hereby discussed in relation to health care ethics of physiotherapy in South Africa.

\section{To stimulate moral imagination}

South Africa does not have a history of respect of moral issues and rights. Students entering physiotherapy training bring divergent moral values in the form of their individual character and personality traits. These were shaped by their families, different cultures and socio-political backgrounds. Physiotherapy training should aim at improving the awareness of students with regard to moral issues around health care, making them understand the relationship of these to everyday human rights issues.

There is an argument that morality cannot be taught and that the teaching of health care ethics cannot reshape the student's personality and ensure ethical practice in the future. However, there is no denying that students do not graduate with their character unaltered or modified by their training. What is important to note is that students enter physiotherapy training as lay people with their own attitudes and behaviours. Through education and socialisation the gap between personal and professional ethical framework is bridged. The teaching of health care ethics is not to inculcate upon students moral beliefs nor to change their personal beliefs. However, physiotherapy has an obligation to expose new members to ethical values that are consistent with their professional roles (Callaghan and Bok, 1980; Hafferty and Frank, 1994). It should also provide students with insights and perceptions that reflect their personal and professional knowledge, behaviour and practice.

\section{To raise an awareness of ethical issues}

Moral behaviour and action involves recognition that a moral issue exists. Ethical dilemmas occur in everyday clinical practice and it is important that physiotherapists have the ability to identify and anticipate potential ethical conflicts (Guccionne, 1980; Andre, 1992; Barnit, 1993).

The TRC document states that the physiotherapy profession lacked a culture of human rights. It also gives the reader the perception that the South African physiotherapy profession believes by virtue of having not transgressed the code of ethics of the profession they were ethical in their practice. This is evident from the statement that "physiotherapists adhered to ethical principles in the treatment of their patients, but most did not think to challenge the requirements of the apartheid era in respect of separate waiting rooms and treatment areas and other areas of petty apartheid" (Physiotherapy submission TRC document 1998). The question we should ask of ourselves is how ethical was physiotherapy practice if it functioned within the Apartheid system?

For physiotherapists to practice in South Africa, their code of practice had to be aligned with the policies of the country, which were immoral. These policies of Apartheid transgressed all the basic principles of health care ethics such as respect of person, justice, confidentiality and beneficience. The profession displayed in the TRC document an inability to see the relationship between human rights and health care ethics, and that there was nothing "petty" about Apartheid. One may therefor conclude that physiotherapy practices were also unethical, be that intentional or uninten- 
tional and the physiotherapy profession in South Africa therefor lacked awareness of ethical issues.

The need to identify and clarify ethical issues within physical therapy practice increases as the profession assumes responsibility of those areas of direct domain... The physical therapist of today in defining the limits of his legal and professional autonomy must examine the practice of his profession from an ethical point of view (Guccionne, 1980).

Barnit (1998) in a survey of occupational therapists and physiotherapists identified 107 day to day ethical issues experienced in clinical practice. Unless physiotherapists are aware of these ethical issues the profession will continue to have problems guaranteeing actions and behaviours of its members in practice that are ethical and credible.

Many authors (Guccionne 1980; Purtillo 1983; Clawson 1994; Triesenberg 1996; Barnit 1998; TRC Physiotherapy document, 1998) have challenged the physiotherapy profession to promote and provide ethical education in physiotherapy education. It is important that physiotherapy education ensures that future generations are aware of ethical issues, will not claim sins of omission and lack of knowledge about human rights abuses as an excuse for not standing up to be counted. It is important for the profession to restore its image and credibility within the country and internationally. Triesenberg (1996) said:

'The integrity and diligence with which a profession examines its unique ethical issues, understands its ethical interaction and develop method of educating its students will largely determine the moral perspective of that profession'.

\section{To develop analytical and communi- cating skills}

Physiotherapists in South Africa were reluctant to respond to the TRC submission document as they felt that there was no point in dwelling on the past (TRC document, 1998). Five years after the new dispensation, transformation of the profession is slow and very painful for some because there is still a reluctance to critically discuss the legacy of Apartheid in physiotherapy education and services, and to look at ways to facilitate change.
Health care ethics must endeavour to equip students with skills to analyse, reason and handle ethical issue raised in practice in a way that will improve ethical judgement and quality practice (Burling et al, 1990; Christakis and Feudtner, 1993; Kopelman, 1995). Without the ability to make ethical decisions, treatments by physiotherapists have the potential to jeopardise the professional credibility and advancement of the profession (Carson, 1994).

Physiotherapy practice most often brings into play different role players (patients, family, other staff members) with different expectations and with potential for conflict. Students need to have negotiation and interpersonal skills to distinguish between facts, opinions, values and reasoned arguments and in the process be able to justify their decisions based on evidence and learn to defend their views and reasons.

\section{To improve tolerance of ambiguity and diversity}

In South Africa there has been a great evolution in the openess and expression of diversity. This has placed great challenges on public, health care and training institutions, to accept that there are many different races and not only one way of expressing and appreciating the meaning of life. This diverse society desires to be cared for by people who are sensitive, understanding and respect their various backgrounds and beliefs.

By taking different points of view into account students should be able to consider moral perspectives and understand issues that cause moral conflict. These abilities will help them explore and define their own personal, social and professional values and their expectations of others in health care.

\section{To elicit a sense of moral obligation and social responsibility}

Physiotherapy practitioners in South Africa believe in a 'hands on' clinical practice where the patient's social background is neglected (Physiotherapy TRC document, 1998). Their perception is frequently that their moral obligation and responsibility is limited to individual patients only. They fail to recognise their responsibility in influencing the socio- political processes that impact on professional practice. The profession needs to recognise that ethical issues and education do not only revolve around individuals.

The profession has a responsibility and obligation to society to speak and participate in decisions and issues that impinge on its professional fields. Important issues in South Africa are:

- Trade off between tertiary rehabilitation and community based rehabilitation

- Allocation of resources between urban and rural sectors

- Access and availability of physiotherapy service in the public sector

- Access and relevancy of physiotherapy education

Morality demands that physiotherapists be prepared to stand up against social and political structures to oppose injustices and inequitable practice in health care.

Students need to be exposed to community issues that impact on health, such as poverty, lack of clean water and sanitation, unemployment and violence. They also need to interact with communities to understand how cultural and religious beliefs influence society in the way they define illness, suffering and disability. These will provide the students with opportunities to learn that health is not limited to disease and that there are other factors that impact on disease and so influence the healing process.

\section{CONCLUSION}

The legacy of apartheid in South Africa cuts deep within the physiotherapy profession. Physiotherapists are facing a great challenge to bridge the gap between white and black professionals and in this way to unite the profession. White physiotherapists may expect the profession to forget the past and to move forward but for the black physiotherapists confession is not enough if it does not involve critical reflection and positive action to make amends. It is only when real change takes place within the profession that they will be able to let go and forgive. Education of physiotherapists about human rights and ethical behaviour within the undergraduate curriculum has been identified as one way 
of achieving reconciliation and a sense of unity. It is envisaged that education in ethics will ensure that future generations of physiotherapists do not forget the past but will understand that rules should not be followed blindly.

\section{REFERENCES}

Ashcroft R, Baron D, Benatar S, Bewley S 1998 Teaching medical ethics and law within the medical education: a model for the UK curriculum. Journal medical ethics, 24, 188-192

Andre J 1992 Learning to see: moral growth during medical training. Journal of medical ethics, , 18; 142- 147

Barnit R 1993 What gives you sleepless nights? Ethical practice in Occupational Therapy, British Journal of Occupational Therapy, June, $56(6), 207-215$

Barnit R 1998, Ethical dilemmas in occupational therapy and physical therapy: a survey of practitioners in the UK National Health Service. Journal of medical ethics, 24: $193-197$

Baylis F, Downie J 1991 Ethics education for Canadian medical students. Aca. Med, 66: 413 $-414$
Burling SJ; Lumley JSP; McCarthy LSL; Mytton JA; Nolan JA; Sissou P; Williams DG; Wright LJ 1990 Review of the teaching of medical ethics in London medical schools. Journal of Medical Ethics, 16, 206 -209

Callahan D, Bok S 1980 The teaching of Ethics in Higher education. Hastings on Hudson; Hastings Center, New York

Carson R 1994 Teaching ethics in the context of the medical humanities. Journal of Medical Ethics, 20, 229-234.

Christakis DA, Feudtner C 1993 Ethics in a short white coat: The ethical dilemmas that medical students confront. Aca.Med. 68: 249 - 254

Clawson AL 1994 The relationship between clinical decision making and ethical decision making. Physiotherapy 80(1) 10-14

Culver et al 1985 Basic curricular goals in medical ethics. N. Engl J. Med, 312: 253- 256

Engelhardt HT 1996 The Foundation of Bioethics. Oxford university press, New York

French S 1992 Health care in Multi -ethnic society. Physiotherapy, 78(20):174- 180

Guccione AA 1980 Ethical issues in physical practice: A survey of physical therapist in New England . Physical Therapy,60:1264-72
Hafferty F, Franks R 1994 The hidden curriculum, ethics teaching and the structure of medical education. Aca Med , 11:861-871

Lebeloane HM 1996 The Review of Ethics teaching in Physiotherapy schools in South Africa, Unpublished

Loewy EH 1996 Textbook of Health Care Ethics. Plenum Press, New York.

Promotion of National Unity and Reconciliation Act 1995 3(1) (d)

Purtillo R 1987 Code of Ethics in Physiotherapy: A retrospective view and look ahead. Physiotherapy Practice,3: 28-34

Purtillo and Cassell 1983 Ethical Dimension in the Health Profession. W.B Saunders, New York

Pond Report in the teaching on Medical Ethics in the UK 1987

Submission by the Physiotherapy profession to the Truth and Reconciliation Commission, 1998 Cape Town

Triesenberg HL 1996 The identification of ethical issues in physical therapy practice Physical Therapy,76:1097-1107

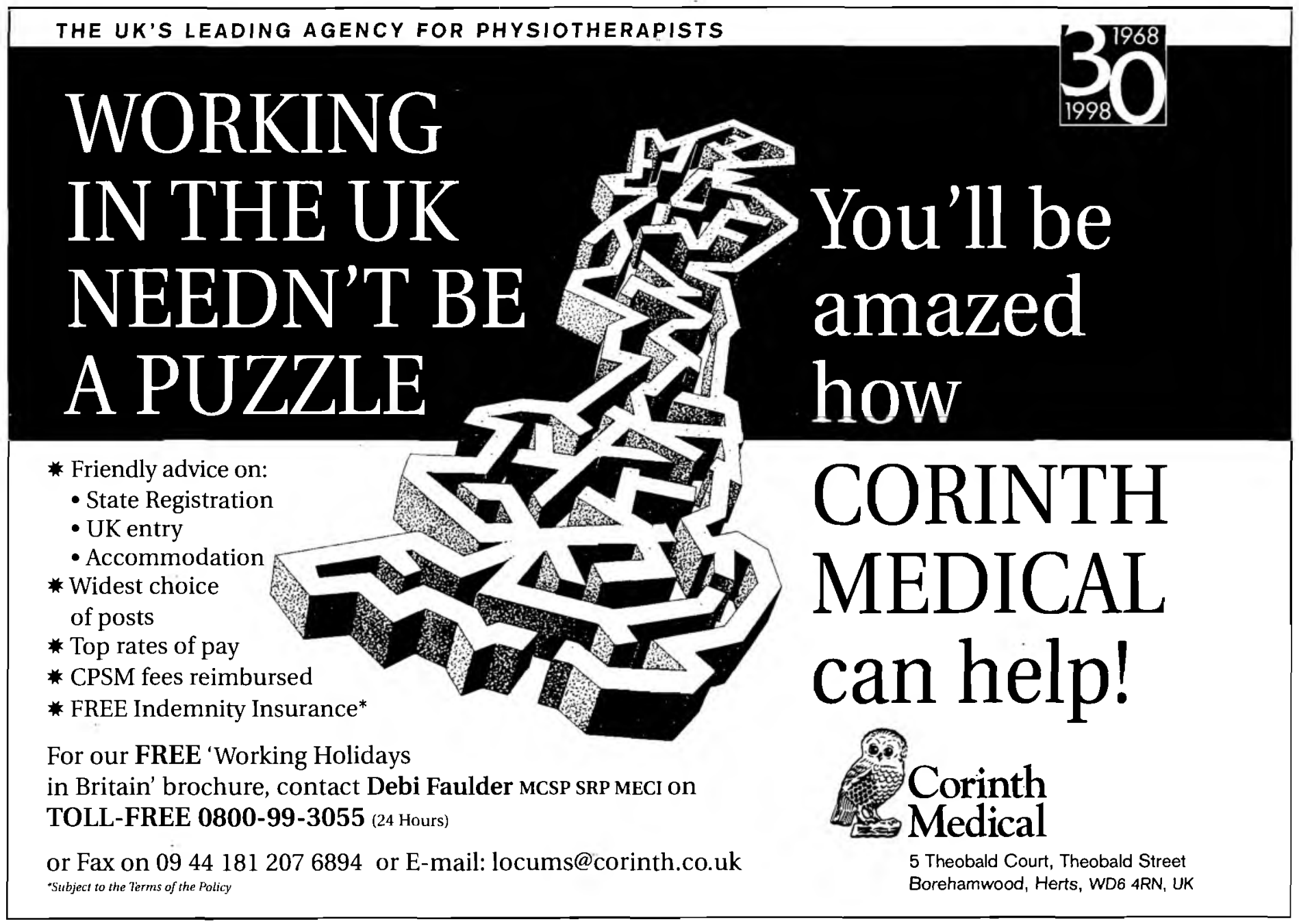

